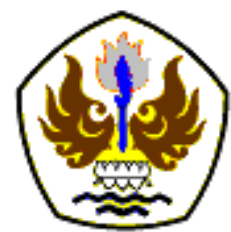

INFOMATEK

Volume 21 Nomor 1 Juni 2019

\title{
STRATEGIC PLANNING EKSPANSI KAPASITAS PRODUKSI SEMEN DARI 4 JUTA TPY MENJADI 7 JUTA TPY DI DEPARTEMEN PENAMBANGAN PADA PABRIK SEMEN PT."X"
}

\author{
Tjutju T. Dimyati ${ }^{\text {*) }}$, Dedy Setyo Oetomo \\ Program Pasca Sarjana Magister Teknik Industri \\ Fakultas Teknik - Universitas Pasundan
}

\begin{abstract}
Abstrak: Keputusan Top Manajemen untuk meningkatkan kapasitas produksi dari 4 juta TPY menjadi 7 Juta TPY menyebabkan perubahan volume bahan baku dan peralatan yang di perlukan untuk mencapai target produksi yang baru. Dukungan ketersediaan bahan baku utama baik dari segi jumlah maupun kualitas merupakan hal yang sangat penting agar aktivitas produksi semen berlangsung sesuai rencana. Selain bahan baku, penyediaan peralatan produksi di departement penambangan juga harus direncanakan agar mampu mengejar target produksi secara efektif dan efisien. Hal ini disebabkan adanya perbedaan antara waktu produksi pada departement raw material preparation, departement clinker burning dan departement finished product dengan waktu produksi di departemen penambangan. Kajian ini dilakukan untuk mendapatkan bahan baku yang diperlukan dengan peningkatan kapasitas produksi tersebut. Selain itu, dilakukan juga perhitungan untuk memperkirakan kebutuhan peralatan tambahan serta biaya yang perlu disediakan. Metode yang digunakan adalah simulasi perhitungan kebutuhan bahan baku dan peralatan dari masing masing proses yang ada di skematik proses pembuatan semen PCC di PT.'X". Hasil perhitungan memperlihatkan bahwa selisih penambahan limestone adalah 2,960 ton, claystone 2,000 ton, silica 88 ton, dan iron ore adalah 62 ton. Kebutuhan alat penambangan bertambah menjadi hampir dua kali lipat, sedangkan biaya yang diperlukan adalah USD 24,776,786.
\end{abstract}

Kata kunci: Ekspansi Kapasitas, Volume Produksi, Spesifikasi Peralatan, Utilitas Peralatan

\section{PENDAHULUAN}

Semen merupakan salah satu komoditi strategis sebagai penunjang perekonomian nasional melalui pembangunan infrastruktur dan perumahan, gedung serta fasilitas umum lainnya. Sebaran industri semen tahun 2018 masih cenderung di Kawasan Indonesia Barat terutama di pulau Jawa dan Sumatera, dan

*) tjutjutarliah@unpas.ac.id

Pertama diterima : 27 Mei 2019

Direvisi : 29 Mei 2019

Disetujui untuk publikasi: Mei 312019 sebagian besar merupakan industri semen yang sudah terintegrasi. Dari perkiraan kapasitas tahun 2018 sebesar 108,6 juta ton, sebanyak 94,3 juta ton merupakan kapasitas pabrik semen terintegrasi sedangkan sisanya sebanyak 14,3 juta ton merupakan kapasitas grinding mill. Untuk Kawasan Indonesia Timur kapasitas produksi baru mencapai 1,6 juta ton dan semuanya sudah terintegrasi. 
Mengantisipasi pertumbuhan pembangunan infrastruktur yang begitu pesat dalam 3 tahun terakhir dan tahun-tahun ke depan, PT. " $X$ ", suatu perusahaan semen di daerah Bayah Banten, mengambil keputusan strategis untuk menambah kapasitas produksi menjadi 7 juta TPY dari semula 4 juta TPY, untuk memenuhi pasar semen di Jawa Barat dan Banten.

Keputusan Top Managemen akan berdampak sangat besar pada produksi bahan baku utama industri semen, yaitu Limestone $\left(\mathrm{CaCO}_{3}\right)$, Claystone $\left(\mathrm{Al}_{2} \mathrm{O}_{3}\right)$, Iron Sand $\left(\mathrm{Fe}_{2} \mathrm{O}_{3}\right)$, dan Silica Sand $\left(\mathrm{Si}_{2} \mathrm{O}_{3}\right)$. Selain itu juga berdampak pada jumlah peralatan yang di perlukan serta dimensi stockpile dari masing masing bahan baku utama industrl semen. Optimasi jumlah produksi pada departemen penambangan merupakan harapan dari manajemen sehingga nantinya investasi dari peralatan akan bisa diminimumkan.

\section{METODOLOGI}

Metode yang di gunakan untuk menyelesaikan permasalahan strategic capacity planning ini adalah dengan melakukan simulasi perhitungan kebutuhan bahan baku dan peralatan dari masing masing proses yang ada di skematik proses pembuatan semen PCC di PT. "X". Pada perencanaan kapasitas ini tipe semen yang diproduksi adalah Portland Composite Cement yang dibuat melalui proses kering (dry process), dimana perbedaan utamanya terletak dalam persiapan/preparasi bahan baku.

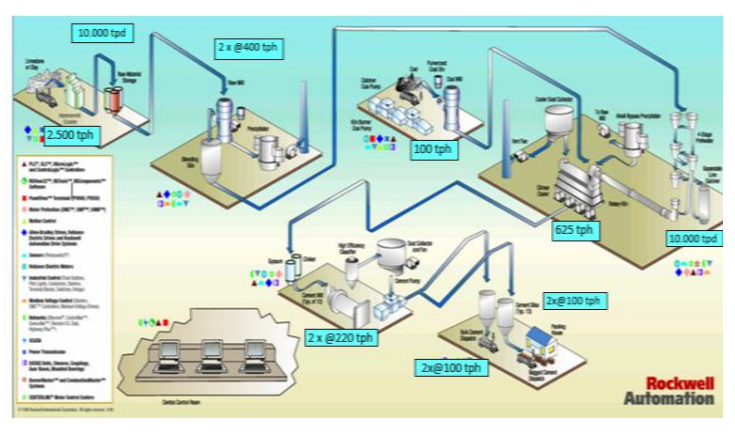

Gambar 1.

Kemampuan Peralatan Utama Pada Produksi semen di PT. "X"

Tabel 1. Jenis Peralatan Produksi Semen di PT X

\begin{tabular}{ll}
\hline \multicolumn{1}{c}{ Proses } & \multicolumn{1}{c}{ Metoda } \\
\hline Mining \& Material & Conventional (blasting), Loading \\
\& Hauling & Two stage (primary and \\
\hline Crushing & secondary) di lokasi quarry \\
\hline Conveying of & Belt conveyors ( 8 km dari \\
Limestone & quarry ke plant) \\
\hline Grinding & Ball Mills with / without \\
& conventional classifier \\
\hline Pyro Processing & Dry ( 4 stage preheater, \\
& Conventional cooler, Single \\
& channel burner) \\
\hline Blending \& Storage & Batch/contiuous-Blending Silos \\
\hline Packing \& Despatch & Bag and Bulk \\
\hline Process Control & Relay Logic / Hard Wired / PLC \\
\hline
\end{tabular}

Proses kering untuk pembuatan semen dipilih sesuai bahan calcareous seperti batu gamping/kapur (limestone) dan bahan argillaceous seperti tanah liat (clay) atau serpih (shale) ditambah silica dari pasir (sand) 
dan oksida besi dari biji/pasir besi (ironore/sand) dihancurkan dengan menggunkan crusher, dikeringkan dan dicampur dengan perbandingan tertentu, kemudian campuran bahan baku ini digiling sampai menjadi bahan baku bubuk (pulverized raw) dengan kehalusan sekurang-kurang $90 \%$ lolos saring 100 mesh sehingga siap diumpankan melalui ujung bagian atas kiln untuk dibakar. Campuran bahan baku yang digiling halus tersebut diumpankan pada atas rotary kiln yang mempunyai kemiringan sekitar $15^{\circ} \mathrm{C}$ sehingga bahan baku dapat bergerak ke bagian bawah rotary kiln sambil dibakar dengan bubuk batu bara pada suhu $1.450^{\circ} \mathrm{C}$ untuk menghasilkan clinker. Jadi panas dari pembakaran batu bara merubah bahan baku semen menjadi clinker yang akan digiling bersama penambahan 4-5\% gypsum $\left(\mathrm{CaSO}_{4} \cdot 2 \mathrm{H}_{2} \mathrm{O}\right)$ dengan ball mill sampai kehalusan 78\% mesh, 200 mesh menjadi semen portland (Alsop [1]).

\subsection{Desain Penelitian}

Di dalam melakukan perencanaan ini maka digunakan skema proses desain perencanaan perhitungan kebutuhan bahan baku dan perhitungan kebutuhan peralatan yang di persyaratkan untuk memenuhi target produksi yang di inginkan.

1. Pengumpulan Data

Pada Tahap ini yang dilakukan adalah mengumpulkan data sebagai berikut.
- Kapasitas terpasang produksi eksisting

- Data proses produksi clinker dan semen, yang didasarkan pada model yang dikembangkan oleh Baby-Jean Robert Mungyeko Bisulandu and Frederic Marias (Bisulandu dkk. [2]), Tianming Gao, et al. [3], dan Xianhong Li dkk. [4]. Dalam hal ini penyesuaian perlu dilakukan terhadap kandungan material pembentuk pcc, kandungan elemen material pembentuk klinker, data peralatan industri semen, data spesifikasi dan kemampuan proses peralatan penambangan, jumlah peralatan penambangan, jumlah peralatan handling, volume dan dimensi stockpile bahan baku utama semen, quarry work time, plant work time, loading losses on quarry, hauling losses on quarry, water contain on material, water contain on each process, serta data koefisien pada proses penambangan.

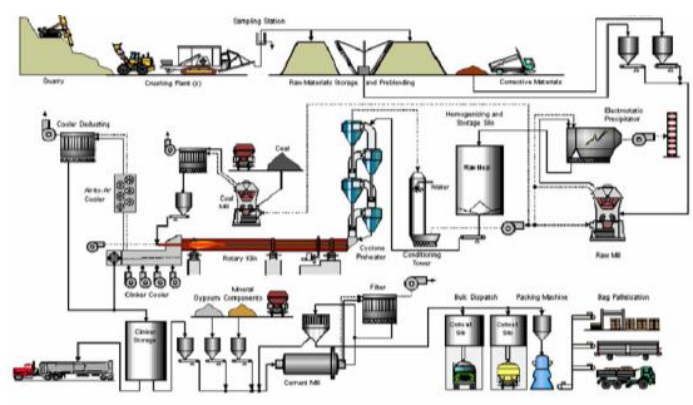

Gambar 2.

Skematik Proses Pembuatan Semen 


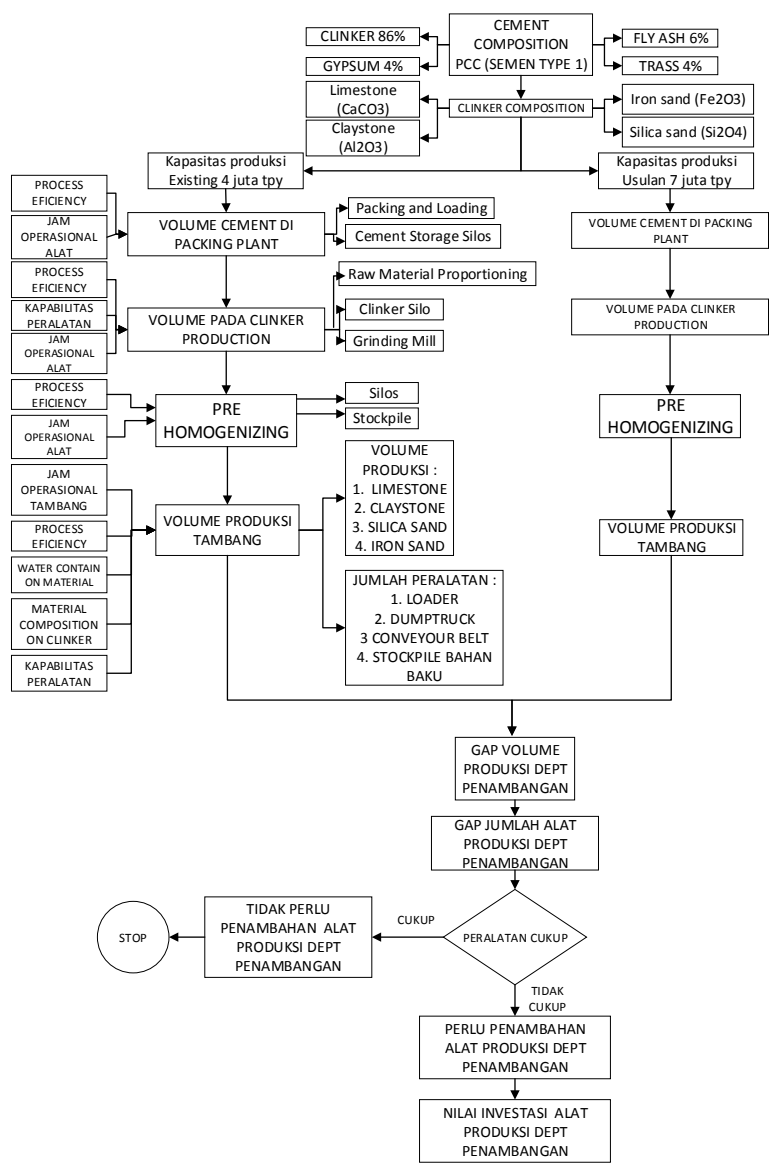

Gambar 3.

\subsection{Formulasi Matematika pada Unit \\ Penambangan Limestone}

\section{Raw-Materials (Cao)}

Process item capacity (ton/year) $\quad=P / s$

Plant time Works

$=$

PTWIS

Process item Quarry capacity (ton/day) =

QDIs =Pls / QDW

Process item Quarry capacity (ton/Hour)

$$
=Q T / s=Q D / s / Q T W
$$

\section{Limestone Mining}

Process item capacity (ton/year)

$$
=P L C(I s)=P(I s) / C Q(I s)
$$

Plant time Works

PTWplc(ls) = PLC(s)/12/PDW

Process item Quarry capacity (ton/day) = QDplc(Is) $=$ PLC (Is)/12/QDW

Process item Quarry capacity (ton/Hour) $=Q T p / s=\left(Q D p / c(l s)^{\star} Q D W\right) / Q T W$

\section{Quarrying}

\section{a) Screening}

Process item capacity $($ ton $/$ year $)=$

$P Q s C(I s)=P L C(I s) / E S C$

Plant time Works

PTWsc(Is) = PQs (Is) $/ 12 / P D W$

Process item Quarry capacity

(ton/day)

$Q D s c(I s)=\left(P T W s c(I s)^{*} P T W\right) / Q D W$

Process item Quarry capacity

(ton/Hour)

$Q T s c(I s)=\left(Q D s c(I s)^{*} Q D W\right) / Q T W$

\section{b) Secondary Crushing}

Process item capacity (ton/year) $=$

$P Q s c r(I s) \quad=P Q s c(I s) / E s c r$

Plant time Works

$\operatorname{PTWscr}(I s)=P Q s c r(I s) / 12 / P D W$

Process item Quarry capacity

(ton/day)

$Q D s c r(I s)=\left(P T W s c r(I s)^{*} P T W\right) / Q D W$

Process item Quarry capacity (ton/Hour)

$Q T s c r(I s)=\left(Q D s c r(I s)^{*} Q D W\right) / Q T W$

c) Primary Crushing 
Process item capacity (ton/year) =

PQpc(Is) = PQscr(Is)/Escr

Plant time Works

$P T W p c(I s)=P Q p c(I s) / 12 / P D W$

Process item Quarry capacity

(ton/day)

$Q D p c(I s)=\left(P T W p c(I s)^{*} P T W\right) / Q D W$

Process item Quarry capacity

(ton/Hour)

$Q T p c(l s) \quad=$

$\left(Q D p c(l s)^{*} Q D W\right) / Q T W$

d) Production included Water

\section{Contains on limestone}

Process item capacity (ton/year) =

$P w c(I s)=P Q p c(I s) /(1-C W / s)$

Plant time Works

$P T W p c(I s)=P w c(I s) / 12 / P D W$

Process item Quarry capacity

(ton/day)

$Q D w c(I s)=\left(P T W w c(I s)^{*} P T W\right) / Q D W$

Process item Quarry capacity

(ton/Hour)

$Q T w c(l s)=\left(Q D w c(I s)^{*} Q D W\right) / Q T W$

e) Production included Hauling

\section{Losses on quarry}

Process item capacity (ton/year) =

$P H q(I s)=P w c(I s) /(1-L h q)$

Plant time Works

PTWhq(Is) = Phq(Is)/12/PDW

Process item Quarry capacity (ton/day)

$Q D h q(I s)=\left(P T W h q(I s)^{*} P T W\right) / Q D W$
Process item Quarry capacity

(ton/Hour)

$Q T h q(I s)=\left(Q D h q(I s)^{*} Q D W\right) / Q T W$

f) Production included Loading Losses on quarry

Process item capacity (ton/year) =

$P l q(I s)=P H q(I s) /(1-L / q)$

Plant time Works

$P T W I q(I s)=P l q(I s) / 12 / P D W$

Process item Quarry capacity

(ton/day)

$Q D I q(I s) \quad=$

(PTWlq(Is)*PTW)/QDW

Process item Quarry capacity

(ton/Hour)

$Q T / q(I s)=\left(Q D / q(I s)^{*} Q D W\right) / Q T W$

Tabel 2. Formulasi Matematika pada Unit

Penambangan Limestone

\begin{tabular}{|c|c|c|c|c|}
\hline \multirow[t]{2}{*}{ No } & \multirow{2}{*}{$\begin{array}{c}\text { Process } \\
\text { item }\end{array}$} & \multirow{2}{*}{$\begin{array}{c}\text { Plant } \\
\text { time } \\
\text { Works }\end{array}$} & $\begin{array}{c}\text { Process } \\
\text { item } \\
\text { capacity } \\
\text { (ton/day) }\end{array}$ & $\begin{array}{l}\text { Process } \\
\text { item cap } \\
\text { (ton/hou) }\end{array}$ \\
\hline & & & $\begin{array}{c}\text { Quarry } \\
\text { time } \\
\text { Works }\end{array}$ & $\begin{array}{c}\text { Quarry } \\
\text { time } \\
\text { Works }\end{array}$ \\
\hline A & $\begin{array}{l}\text { Raw- } \\
\text { Materials }\end{array}$ & & & \\
\hline 1 & $\mathrm{CaO}$ & PTW $_{\text {Is }}$ & $\mathrm{QD}_{\mathrm{ls}}$ & $\mathrm{QT}_{\text {Is }}$ \\
\hline B & $\begin{array}{l}\text { Limestone } \\
\text { Mining }\end{array}$ & & & \\
\hline 2 & $\begin{array}{l}\mathrm{CaO} \\
\text { average } \\
\text { contains } \\
\text { limestone }\end{array}$ & & & \\
\hline 3 & $\begin{array}{l}\text { Limestone } \\
\text { Consumption } \\
\text { of Plant }\end{array}$ & PTWplc $_{(\mid \mathrm{s})}$ & $\mathrm{QDplc}_{(\mathrm{ls})}$ & QTpls \\
\hline
\end{tabular}




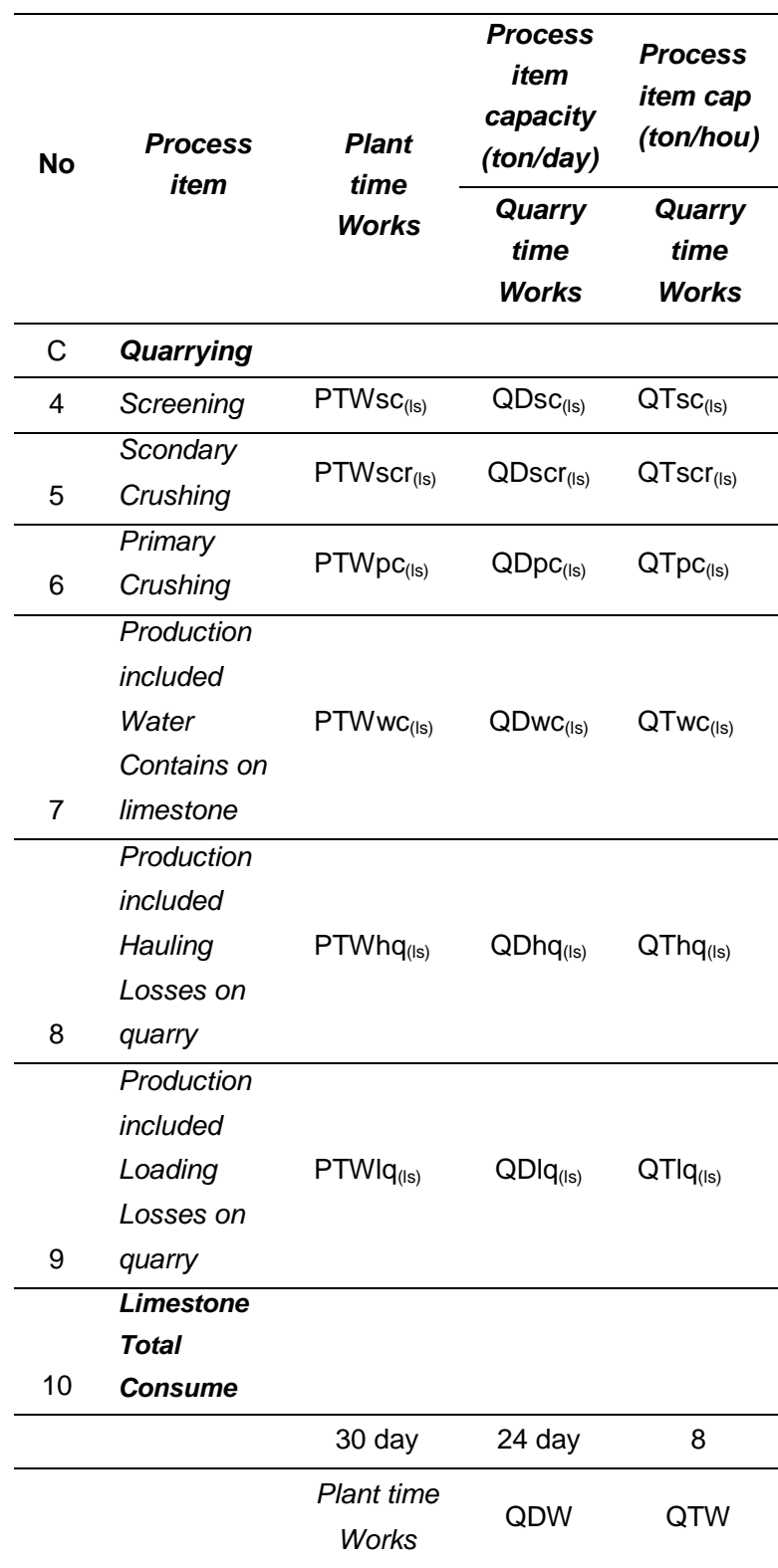

Dengan cara yang sama dilakukan perhitungan kebutuhan material pada unit penambangan Silika, unit penambangan Iron Ore, dan unit penambagan Claystone seperti ditunjukkan pada Tabel 3 hingga Tabel 5.
Tabel 3. Formulasi Matematika pada Unit Penambangan Silika

\begin{tabular}{|c|c|c|c|c|}
\hline \multirow[t]{2}{*}{ No } & \multirow{2}{*}{$\begin{array}{c}\text { Process } \\
\text { item }\end{array}$} & & $\begin{array}{c}\text { Process } \\
\text { item } \\
\text { capacity } \\
\text { (ton/day) }\end{array}$ & $\begin{array}{c}\text { Process } \\
\text { item } \\
\text { capacity } \\
\text { (ton/hour) }\end{array}$ \\
\hline & & $\begin{array}{c}\text { Plant } \\
\text { time } \\
\text { Works }\end{array}$ & $\begin{array}{c}\text { Quarry } \\
\text { time } \\
\text { Works }\end{array}$ & $\begin{array}{c}\text { Quarry } \\
\text { time } \\
\text { Works }\end{array}$ \\
\hline A & $\begin{array}{l}\text { Raw- } \\
\text { Materials }\end{array}$ & & & \\
\hline 1 & $\mathrm{Si}_{2} \mathrm{O}_{4}$ & PTWio & $\mathrm{QD}_{\mathrm{si}}$ & QTsi = \\
\hline$B$ & $\begin{array}{l}\text { Claystone } \\
\text { Mining }\end{array}$ & & & \\
\hline 2 & $\begin{array}{l}\text { SiO average } \\
\text { contains } \\
\text { Claystone }\end{array}$ & & & \\
\hline 3 & $\begin{array}{l}\text { Silica } \\
\text { Consumption } \\
\text { of Plant }\end{array}$ & $\mathrm{PTWpc}_{(\mathrm{io})}$ & $\mathrm{QDpc}_{(\mathrm{si})}$ & $\mathrm{QT}_{\mathrm{si}}$ \\
\hline C & Quarrying & & & \\
\hline 4 & Screening & $\mathrm{PTWsC}_{(\mathrm{io})}$ & $\mathrm{QDsc}_{(\mathrm{si})}$ & $\mathrm{QTsC}_{(\mathrm{si})}$ \\
\hline 7 & $\begin{array}{l}\text { Water } \\
\text { Contains on } \\
\text { Silica Sand }\end{array}$ & PTWWC $_{(i o)}$ & $\mathrm{QDwc}_{(\mathrm{si})}$ & $\mathrm{QTwC}_{(\mathrm{si})}$ \\
\hline 8 & $\begin{array}{l}\text { Hauling } \\
\text { Losses on } \\
\text { quarry }\end{array}$ & PTWhq $_{(i o)}$ & $\mathrm{QDhq}_{(\mathrm{si})}$ & $\mathrm{QThq}_{(\mathrm{si})}$ \\
\hline 9 & $\begin{array}{l}\text { Loading } \\
\text { Losses on } \\
\text { quarry }\end{array}$ & PTWlq(si) & QDlq $_{(\mathrm{si})}$ & QTIq $($ (si) \\
\hline 10 & $\begin{array}{l}\text { Silica Total } \\
\text { Consume }\end{array}$ & & & 0.0 \\
\hline & & 30day & 30 day & 8.0 \\
\hline & & $\begin{array}{c}\text { Plant time } \\
\text { Works }\end{array}$ & $\begin{array}{c}\text { Quarry } \\
\text { time Works }\end{array}$ & $\begin{array}{c}\text { Quarry } \\
\text { time } \\
\text { Works }\end{array}$ \\
\hline
\end{tabular}


Tabel 4. Formulasi Matematika pada Unit Penambangan Iron Ore

\begin{tabular}{|c|c|c|c|c|}
\hline \multirow[t]{2}{*}{ No } & \multirow[t]{2}{*}{ Process item } & & $\begin{array}{c}\text { Process } \\
\text { item } \\
\text { capacity } \\
\text { (ton/day) }\end{array}$ & $\begin{array}{c}\text { Process } \\
\text { item } \\
\text { capacity } \\
\text { (ton/hour) }\end{array}$ \\
\hline & & $\begin{array}{c}\text { Plant } \\
\text { time } \\
\text { Works }\end{array}$ & $\begin{array}{c}\text { Quarry } \\
\text { time } \\
\text { Works }\end{array}$ & $\begin{array}{c}\text { Quarry } \\
\text { time } \\
\text { Works }\end{array}$ \\
\hline$A$ & Raw-Materials & & & \\
\hline 1 & $\mathrm{Fe}_{2} \mathrm{O} 3$ & PTW $_{\text {io }}$ & $Q D_{\text {io }}$ & $Q T_{\text {io }}$ \\
\hline \multirow[t]{2}{*}{$B$} & $\begin{array}{l}\text { Claystone } \\
\text { Supply }\end{array}$ & & & \\
\hline & $\begin{array}{l}\text { FeO average } \\
\text { on Raw } \\
\text { Material }\end{array}$ & & & \\
\hline 2 & $\begin{array}{l}\text { Iron Ore } \\
\text { Consumption } \\
\text { of Plant }\end{array}$ & $\mathrm{PTWpc}_{(\mathrm{io})}$ & $\mathrm{QDpc}_{(\mathrm{io})}$ & QTio \\
\hline$C$ & Quarrying & & & \\
\hline 4 & Screening & $\mathrm{PTWSC}_{(\mathrm{io})}$ & $\operatorname{QDsc}_{(\mathrm{io})}$ & $\mathrm{QTSC}_{(\mathrm{io})}$ \\
\hline 7 & $\begin{array}{l}\text { Water Contains } \\
\text { on Iron Ore }\end{array}$ & $\mathrm{PTWWc}_{(\mathrm{io})}$ & $\mathrm{QDwc}_{(\mathrm{io})}$ & QTwC $(\mathrm{io})$ \\
\hline \multirow[t]{2}{*}{8} & $\begin{array}{l}\text { Hauling Losses } \\
\text { on quarry }\end{array}$ & 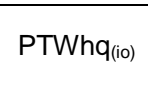 & QDhq $_{(\mathrm{io})}$ & $\mathrm{QThq}_{\text {(io) }}$ \\
\hline & $\begin{array}{l}\text { Loading } \\
\text { Losses on } \\
\text { quarry }\end{array}$ & 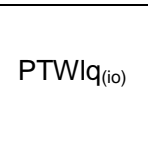 & QDlq $_{(\text {io) }}$ & $\mathrm{QTlq}_{\text {(io) }}$ \\
\hline 9 & $\begin{array}{l}\text { Iron Sand } \\
\text { Total } \\
\text { Consumption }\end{array}$ & & & \\
\hline \multirow{2}{*}{10} & & 30 day & 30 day & 8 \\
\hline & & $\begin{array}{c}\text { Plant } \\
\text { time } \\
\text { Works }\end{array}$ & QDW & QTW \\
\hline
\end{tabular}

Tabel 5. Formulasi Matematika pada Unit Penambangan Claystone

\begin{tabular}{|c|c|c|c|c|}
\hline \multirow[t]{2}{*}{ No } & Process item & & $\begin{array}{c}\text { Process } \\
\text { item } \\
\text { capacity } \\
\text { (ton/day) }\end{array}$ & $\begin{array}{l}\text { Process } \\
\text { item } \\
\text { capacity } \\
\text { (ton/hour) }\end{array}$ \\
\hline & & $\begin{array}{c}\text { Plant } \\
\text { time } \\
\text { Works }\end{array}$ & $\begin{array}{c}\text { Quarry } \\
\text { time } \\
\text { Works }\end{array}$ & $\begin{array}{c}\text { Quarry } \\
\text { time } \\
\text { Works }\end{array}$ \\
\hline
\end{tabular}

\begin{tabular}{cllll}
\hline $\mathrm{A}$ & Raw-Materials & & & \\
\hline 1 & $\mathrm{Al}_{2} \mathrm{O}_{3}$ & $\mathrm{PTW}_{\mathrm{Al}}$ & $\mathrm{QD}_{\mathrm{Al}}$ & $\mathrm{QT}_{\mathrm{Al}}$ \\
\hline & Claystone & & \\
$\mathrm{B}$ & Mining & & \\
\hline & & & \\
& $\mathrm{A} / \mathrm{O}_{2}$ average & &
\end{tabular}
contains

2 Claystone Claystone Consumption of $\quad \mathrm{PTWpc}_{(\mathrm{Al})}$

\begin{tabular}{|c|c|c|c|c|}
\hline 3 & Plant & & $\mathrm{QDpc}_{(\mathrm{Al})}$ & QTAI \\
\hline $\mathrm{C}$ & Quarrying & & & \\
\hline 4 & Screening & PTWsc $_{(A l)}$ & $\mathrm{QDsc}_{(\mathrm{Al})}$ & $\mathrm{QTsc}_{(\mathrm{Al})}$ \\
\hline 5 & $\begin{array}{l}\text { Scondary } \\
\text { Crushing }\end{array}$ & $\operatorname{PTWscr}_{(\mathrm{Al})}$ & $\operatorname{QDscr}_{(\mathrm{Al})}$ & $\mathrm{QTss}_{(\mathrm{Al})}$ \\
\hline 7 & $\begin{array}{l}\text { Water Contains } \\
\text { on Claystone }\end{array}$ & PTWWc $_{(\mathrm{Al})}$ & $\mathrm{QDwC}_{(\mathrm{Al})}$ & $\mathrm{QTwC}_{(\mathrm{Al})}$ \\
\hline 8 & $\begin{array}{l}\text { Hauling Losses } \\
\text { on quarry }\end{array}$ & PTWhq $_{(\mathrm{Al})}$ & $\mathrm{QDhq}_{(\mathrm{Al})}$ & QThq $_{(\mathrm{Al})}$ \\
\hline 9 & $\begin{array}{l}\text { Loading Losses } \\
\text { on quarry }\end{array}$ & PTWlq $($ Al) & $\mathrm{QDlq}_{(\mathrm{Al})}$ & $\mathrm{QTIq}_{(\mathrm{Al})}$ \\
\hline
\end{tabular}

10 Claystone Total

\begin{tabular}{ccc}
\hline 30 day & 30 day & 8 hour \\
\hline Plant time & Quarry & Quarry \\
Works & time & time \\
& Works & Works \\
\hline
\end{tabular}


Langkah selanjutnya adalah melakukan perhitungan kebutuhan peralatan dan utilitas peralatan penambangan, dengan mengacu pada Cement Formula Handbook [5], Deolalkar, S.P., [6], dan Sinoma Technology \&
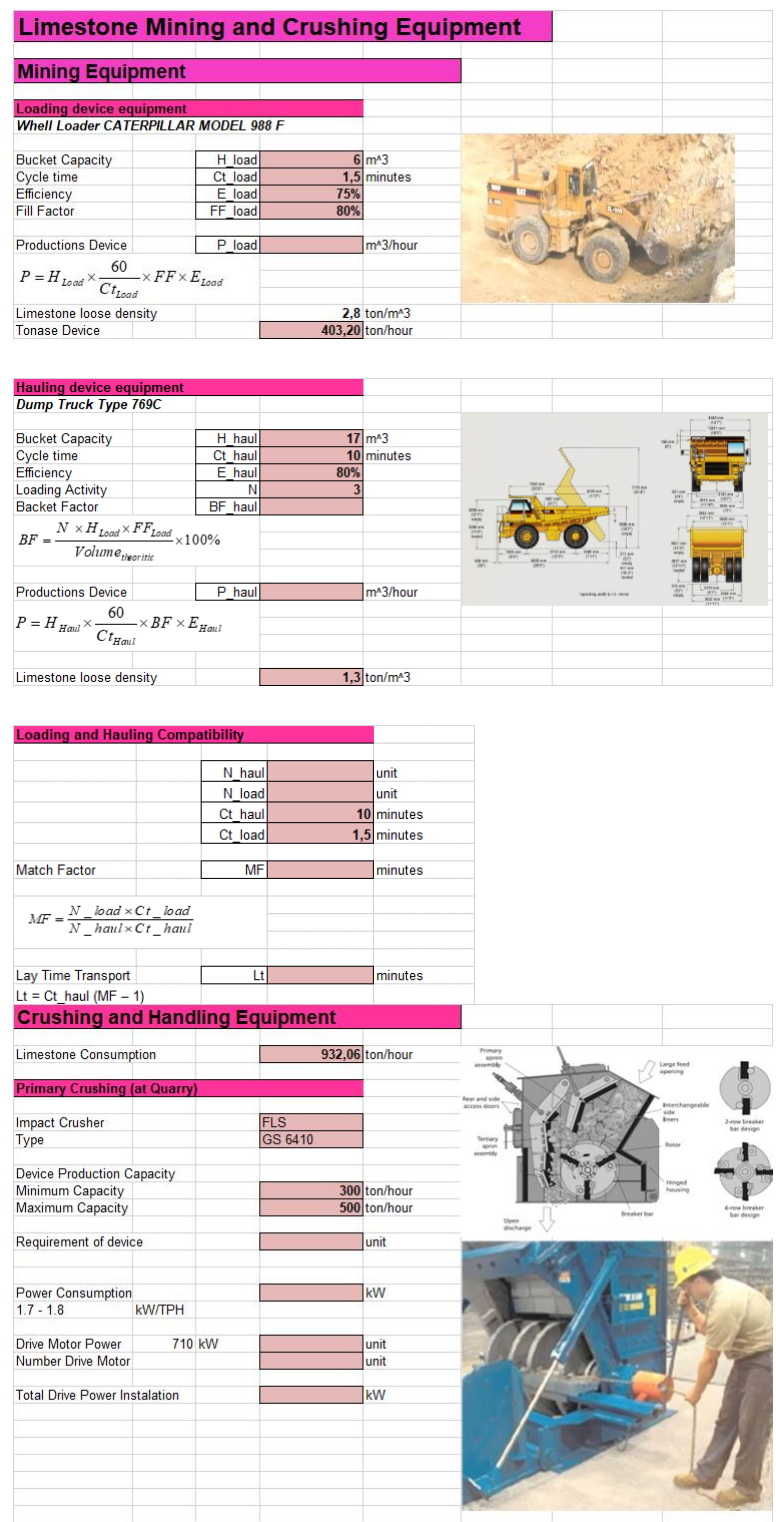

Equipment Group CO., LTD. [7]. Perhitungan dilakukan degan simulasi seperti pada Gambar 3.
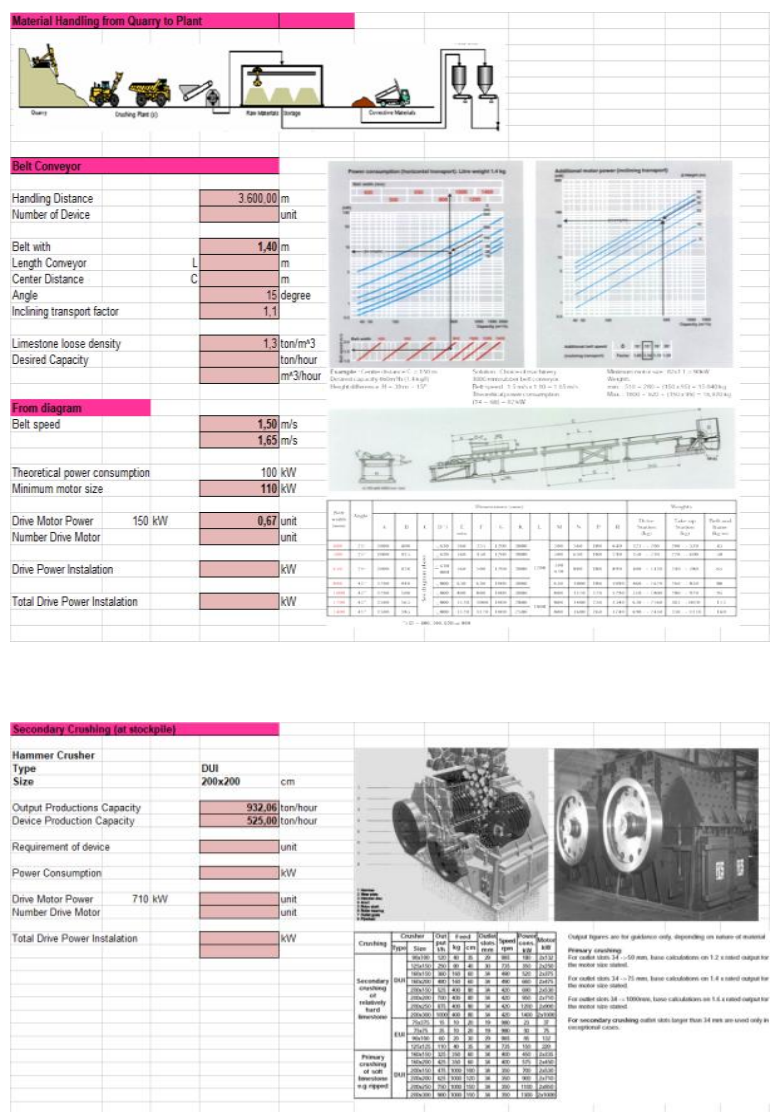

Gambar 3.

Modul Simulasi Perhitungan Kebutuhan Peralatan dan Utiitas Peralatan Penambangan 


\section{ANALISIS DAN PEMBAHASAN}

\subsection{Volume Bahan Baku yang dibutuhkan}

Dari model, skema proses dan perhitungan kebutuhan, maka di harapkan dari model ini akan diperoleh:

1. Volume Kebutuhan Bahan baku Limestone $\left(\mathrm{CaCO}_{3}\right)$ untuk KPT 4 Juta TPY adalah 3.133 tph dan KPT 7 Juta TPY adalah 6.093 tph

2. Volume Kebutuhan Bahan baku Claystone $\left(\mathrm{Al}_{2} \mathrm{O}_{3}\right)$ untuk KPT 4 Juta TPY adalah 2118 tph dan KPT 7 Juta TPY. 4118 tph

3. Volume Kebutuhan Bahan baku Silica $\left(\mathrm{Si}_{2} \mathrm{O}_{4}\right)$ untuk KPT 4 Juta TPY adalah 92.9 tph dan KPT 7 Juta TPY adalah 180.7 tph

4. Volume Kebutuhan Bahan baku Iron Sand $\left(\mathrm{Fe}_{2} \mathrm{O}_{3}\right)$ untuk KPT 4 Juta TPY adalah 66 tph dan KPT 7 Juta TPY adalah 128 tph

5. Kebutuhan Bahan bakuu Penunjang produksi

Untuk Kpt 4 juta TPY membutuhkan gypsum 18.46 tph, Fly Ash 27.68 tph dan Trass sebanyak 18.46 tph

Untuk Kpt 7 juta TPY membutuhan gypsum 35.89 ph, Fly Ash 53.83 tph dan Trass 35.89 tph

\subsection{Kemampuan Alat yang dipergunakan Untuk Kpt 4 Juta Tpy}

a. Circular Stacker \& Reclaimer for Limestone

Circular Stacker \& Reclaimer for Limestone yang dipergunakan pabrik semen adalah berbentuk dome dengan volume stacker adalah 100.000 ton dan kemampuan reclaimer adalah 3000 tph. Volume sebanyak ini dipergunakan untuk mendukung operasional pabrik selama 10 hari produksi dengan utilitas reclaimer $43 \%$.

b. Conveyour Belt

Conveyour belt yang dioperasikan saat ini adalah double deck Insulated Coveyour belt dengan kemampuan angkut 3000 tph dan beroperasi selama 8 jam perhari. Tingkat Utilitas dari alat ini adalah 84\%.

c. Quarry Loading and Hauling

\section{Limestone} Jumlah alat yang ada saat ini untuk aktivitas loading adalah sejumlah 4 unit dengan jenis wheel loader adalah Komatsu WA 350. Dengan jumlah alat tersebut maka utilitas dari alat loader ini adalah $80 \%$.

2. Claystone

Jumlah alat untuk aktivitas loading yang ada saat ini adalah 5 unit dengan jenis wheel loader Komatsu WA 350. Dengan jumlah alat tersebut maka utilitas dari alat loader ini adalah $89 \%$. 


\section{Silica}

Jumlah alat untuk aktivitas loading yang ada saat ini adalah 1 unit dengan jenis wheel loader Komatsu WA 350. Dengan jumlah alat tersebut maka utilitas dari alat loader ini adalah $47 \%$.

4. Iron Ore (Saat ini Tidak melakukan penambangan sendiri)

Jumlah alat untuk aktivitas loading yang ada saat ini adalah 1 unit dengan jenis wheel loader Komatsu WA 350. Dengan jumlah alat tersebut maka utilitas dari alat loader ini adalah 34\%.

\section{d. Quarry Hauling}

\section{Limestone}

Untuk bahan tambang limestone, aktivitas hauling menggunakan conveyor belt dengan kapasitas 3000 tph, Tingkat Utilitas dari alat Hauling ini adalah 84\%. .

\section{Claystone}

Jumlah alat untuk aktivitas hauling yang ada saat ini adalah 20 unit dengan jenis hauling device Dump Truck Type Hino fm 260 Ti. Dengan jumlah alat tersebut maka utilitas dari alat loader ini adalah $70 \%$.

3. Silica

Jumlah alat untuk aktivitas hauling yang ada saat ini adalah 3 unit dengan jenis hauling device Dump Truck Type Hino fm 260 Ti. Dengan jumlah alat tersebut maka utilitas dari alat loader ini adalah 93\%.

4. Iron Ore (Saat ini Tidak melakukan penambangan sendiri)

Jumlah alat untuk aktivitas hauling yang ada saat ini adalah 3 unit dengan jenis hauling device Dump Truck Type Hino fm $260 \mathrm{Ti}$. Dengan jumlah alat tersebut maka utilitas dari alat loader ini adalah $53 \%$.

\section{e. Quarry Crushing}

Hazemag \& EPR GmbH telah memasok alat penghancur besar untuk Sinoma International Engineering Co., Ltd. Di pasangkan pada PT Cemindo Gemilang. Alat penghancur yang akan dikirim oleh Hazemag terdiri dari apron feeder yang besar, pengumpan wobbler untuk prapenyaringan dan penghancur dampak, yaitu dengan diameter rotor $2,5 \mathrm{~m}$ dan lebar rotor 3,0 m, impact crusher terbesar keluar dari berbagai produk Hazemag. Apron feeder yang lebih kecil lainnya memastikan bahwa dua bahan baku yang berbeda dapat diproses secara bersamaan.

\subsection{Kemampuan Alat Yang Di Pergunakan Untuk Kpt 7 Juta TPY}

a. Circular Stacker \& Reclaimer for Limestone

Circular Stacker \& Reclaimer for Limestone yang di pergunakan pabrik 
semen adalah berbentuk dome dengan volume stacker 100.000 ton sebanyak 2 limestone stockpile dengan kemampuan reclaimer 2×3000 tph. Ini dipergunakan untuk mendukung operasional pabrik selama 10 hari produksi dengan utilitas reclaimer $60 \%$.

b. Conveyour Belt

Conveyour belt yang dioperasikan saat ini adalah double deck Insulated Coveyour belt dengan kemampuan angkut 3000 tph. Perlu di tambah 1 line lagi dengan kapasitas yang sama dan beroperasi selama 8 jam perhari. Tingkat Utilitas alat ini adalah $82 \%$.

\section{c. Quarry Loading and Hauling}

\section{Limestone}

Jumlah alat yang ada saat ini untuk aktivitas loading adalah sejumlah 7 unit dengan jenis wheel loader adalah Komatsu WA 350. Dengan jumlah alat tersebut maka utilitas dari alat loader ini adalah 89\%.

\section{Claystone}

Jumlah alat yang ada saat ini untuk aktivitas loading adalah sejumlah 9 unit dengan jenis wheel loader adalah Komatsu WA 350. Dengan jumlah alat tersebut maka utilitas dari alat loader ini adalah 97\%.

3. Silica

Jumlah alat yang ada saat ini untuk aktivitas loading adalah sejumlah 1 unit dengan jenis wheel loader adalah Komatsu WA 350. Dengan jumlah alat tersebut maka utilitas dari alat loader ini adalah 93\%.

4. Iron Ore (Saat ini Tidak melakukan penambangan sendiri)

Jumlah alat yang ada saat ini untuk aktivitas loading adalah sejumlah 1 unit dengan jenis wheel loader adalah Komatsu WA 350. Dengan jumlah alat tersebut maka utilitas dari alat loader ini adalah $66 \%$.

\section{d. Quarry Hauling}

\section{Limestone}

Untuk bahan tambang limestone, aktivitas hauling menggunakan conveyor belt dengan kapasitas $2 \mathrm{x}$ 3000 tph, Tingkat Utilitas dari alat Hauling ini adalah $82 \%$.

\section{Claystone}

Jumlah alat yang ada saat ini untuk aktivitas hauling adalah sejumlah 36 unit dengan jenis hauling device adalah Dump Truck Type Hino fm 260 Ti. Dengan jumlah alat tersebut maka utilitas dari alat loader ini adalah $78 \%$.

\section{Silica}

Jumlah alat yang ada saat ini untuk aktivitas hauling adalah sebanyak 4 unit dengan jenis hauling device Dump Truck Type Hino fm 260 Ti. Dengan jumlah alat tersebut maka utilitas dari alat loader ini adalah 99\%. 
4. Iron Ore (Saat ini Tidak melakukan penambangan sendiri)

Jumlah alat yang ada saat ini untuk aktivitas hauling adalah sebanyak 3 unit dengan jenis hauling device Dump Truck Type Hino fm 260 Ti. Dengan jumlah alat tersebut maka utilitas dari alat loader ini adalah 57\%.

e. Quarry Crushing

Hazemag \& EPR GmbH telah memasok alat penghancur besar untuk Sinoma International Engineering Co., Ltd. Di pasangkan pada PT Cemindo Gemilang, yang akan membangun pabrik untuk kapasitas 10.000 t/d di Bayah. Total kapasitas crusher adalah $2 \times 2.500$ tph. Alat ini beroperasi dengan kapasitas penuh untuk memenuhi kebutuhan hasil crushing bagi operasional pabrik.

\subsection{Disparitas Kebutuhan Bahan Baku}

Tabel 6 memperlihatkan resume disparitas kebutuhan bahan baku utama produksi semen.

Tabel 6. Resume Disparitas Kebutuhan Bahan baku

\begin{tabular}{cccc}
\hline $\begin{array}{c}\text { Bahan } \\
\text { Baku }\end{array}$ & KPT 4 Juta TPY & KPT 7 Juta TPY & \multirow{2}{*}{ Selisih } \\
\cline { 2 - 3 } & Ton per hour & Ton per hour & \\
\hline Limestone & 3,134 & 6,094 & 2,960 \\
\hline Claystone & 2,118 & 4,119 & 2,000 \\
\hline Silica & 93 & 181 & 88 \\
\hline Iron Ore & 66 & 128 & 62 \\
\hline
\end{tabular}

\subsection{Disparitas Kebutuhan Alat}

Kebutuhan tambahan alat penambangan pada ekspansi kapasitas produksi dari 4 juta tpy menjadi 7 juta TPY adalah seperti ditunjukkan pada Tabel 7.

Tabel 7. Disparitas Kebutuhan Alat Penambangan

\begin{tabular}{|c|c|c|c|c|}
\hline \multirow[b]{2}{*}{ No } & \multirow[b]{2}{*}{ Peralatan Produksi Semen } & \multicolumn{2}{|c|}{ Jumlah Alat } & \multirow[b]{2}{*}{$\begin{array}{c}\text { Tambah } \\
\text { Alat }\end{array}$} \\
\hline & & $\begin{array}{l}4 \\
\text { juta } \\
\text { Tpy }\end{array}$ & $\begin{array}{l}7 \\
\text { juta } \\
\text { Tpy }\end{array}$ & \\
\hline 1 & Loading device equipment & 11 & 18 & 7 \\
\hline 2 & Hauling device equipment & 26 & 44 & 18 \\
\hline 3 & $\begin{array}{l}\text { Primary Crushing (at } \\
\text { Quarry) }\end{array}$ & 1 & 2 & 1 \\
\hline 4 & $\begin{array}{l}\text { Secondary Crushing (at } \\
\text { stockpile) }\end{array}$ & 3 & 5 & 2 \\
\hline 5 & $\begin{array}{l}\text { Material Handling from } \\
\text { Quarry to Plant }\end{array}$ & 30 & 60 & 30 \\
\hline 6 & $\begin{array}{l}\text { Vibrating feeder (at } \\
\text { stockpile) }\end{array}$ & 15 & 26 & 11 \\
\hline
\end{tabular}

\subsection{Estimasi Tambahan Investasi}

Perhitungan estimasi biaya investasi dilakukan dengan mengacu pada Olayinka S. Ohunakin, dkk. [8]. Pengadaan alat di unit penambangan bahan baku semen dilakukan dengan mengasumsikan konversi nilai USD $=R p$. 14.000. Estimasi biaya pengadaan alat di unit penambangan bahan baku semen adalah seperti ditunjukkan pada Tabel 8. 
Tabel 8. Estimasi Tambahan Investasi Peralatan

Penambangan

\begin{tabular}{|c|c|c|c|c|c|}
\hline No & $\begin{array}{c}\text { Peralatan } \\
\text { Produksi } \\
\text { Semen }\end{array}$ & $\begin{array}{l}\text { Jml } \\
\text { Alat }\end{array}$ & Spek & $\begin{array}{c}\text { Est Harga } \\
\text { Satuan } \\
\text { (USD) }\end{array}$ & $\begin{array}{c}\text { Total } \\
\text { Harga } \\
\text { (USD) }\end{array}$ \\
\hline & & & Wheel & & \\
\hline & Loading & & Loader & & \\
\hline & device & & KOMATSU & & \\
\hline \multirow[t]{4}{*}{1} & equipment & 7 & WA 350 & 60,714 & 425,000 \\
\hline & & & Dump & & \\
\hline & Hauling & & Truck Type & & \\
\hline & device & & Hino fm 260 & & \\
\hline \multirow[t]{3}{*}{2} & equipment & 18 & $\mathrm{Ti}$ & 66,429 & $1,195,714$ \\
\hline & Primary & & Impact & & \\
\hline & Crushing (at & & crusher HPI & & \\
\hline \multirow[t]{2}{*}{3} & Quarry) & 1 & 2230 & $6,071,429$ & $6,071,429$ \\
\hline & Secondary & & & & \\
\hline \multirow[t]{4}{*}{4} & $\begin{array}{l}\text { Crushing (at } \\
\text { stockpile) }\end{array}$ & 2 & FLS DUI & $1,964,286$ & $3,928,571$ \\
\hline & Material & & & & \\
\hline & Handling & & & & \\
\hline & from Quarry & & Conveyour & & \\
\hline \multirow[t]{2}{*}{5} & to Plant & 8,000 & Sinomac & 1,464 & $11,714,286$ \\
\hline & $\begin{array}{l}\text { Vibrating } \\
\text { feeder (at }\end{array}$ & & GZD- & & \\
\hline 6 & stockpile) & 11 & $1300 \times 4900$ & 131,071 & $1,441,786$ \\
\hline
\end{tabular}

$24,776,786$

\section{KESIMPULAN}

1. Peralatan di unit penambangan masih mampu untuk mendukung produksi dengan kapasitas 4 juta tpy.

2. Disparitas kebutuhan bahan baku utama untuk limestone adalah 2,960 ton, claystone 2,000 ton, silica 88 ton, dan iron ore 62 ton

3. Jumlah kebutuhan tambahan alat penambangan pada ekspansi kapasitas produksi dari 4 juta tpy menjadi 7 juta TPY berkisar antara 63-100\%.
4. Estimasi total biaya pengadaan alat di unit penambangan bahan baku semen adalah USD 24,776,786.

\section{DAFTAR PUSTAKA}

[1] Alsop, P.A. The Cement Plant Operation Handbook, 6th Edition. Cemex Industry Publisher, 2014.

[2] Bisulandu, B.J.R.M., Marias, F. Modeling of cement clinker chemistry and engineering of cement manufacturing process: State of the art. International Journal of Innovation and Applied Studies, Vol. 25 No. 2, pp. 528-551, 2019.

[3] Gao, T., Shen, L., Shen, M., Liu, T., Chen, F. Analysis of material flow and consumption in cement production process, Journal of Cleaner Production, Vol. 112, part 1, pp. 553-565, 2016.

[4] Li, X., Yu, H., Yuan, M. Modeling and Optimization of Cement Raw Materials Blending Process. Mathematical Problems in Engineering, Vol. 2012, article ID 392197, 30 p., 2012.

[5] Cement Formula Handbook. R R District, Hyderabad: Published by Confederation of Indian Industry, 2009.

[6] Deolalkar, S.P. Handbook for Designing Cement Plants. New Delhi: BS Publications, 2009.

[7] Sinoma Technology \& Equipment Group CO., LT. Tianjin Cement Industry Design \& 
Infomatek Volume 21 Nomor 1 Juni 2019 : 41 - 54

Research Institute Co., 2015.

[8] Ohunakin, O.S., Leramo, O., Abidakun, O.A., Odunfa, M.K., Bafuwa, O.B. Energy and Cost Analysis of Cement Production Using the Wet and Dry Processes in
Nigeria. Energy and Power Engineering, Vol. 05, No. 02, p. 537-550, 2013. 